УДК 821.163.41-1.09:398 Караџић, Вук Стефановић https://doi.org/10.18485/msc50_vuk_trsic.2021.ch12

\author{
Хатиџа Крњевић
}

\title{
ОДНОС ВУКА КАРАЏИЋА ПРЕМА ПЕСМАМА „НА МЕЪИ”
}

Сакупљајући, изучавајући и класификујући народне песме, Вук Караџић уочио је специфичности песама „на међи” између женских и јуначких, како их је он сам назвао. Својим одређењем Вук је био близу широј и обухватнијој дефиницији прелазних, мешовитих врста усмене поезије које су у науци означене појмовима балада и романса.

Већ у својој првој Пјеснарици из 1814. године Вук се непосредно суочио не само са нашом најпознатијом баладом већ и са потребом откривања изворног текста песме која се нашла у оном малом кругу записаних песама што су угледале светлост дана пре почетка Вуковог рада. Своју прву редакцију Хасанаганице Вук је донео руководећи се жељом да протумачи спорна места онако како је он сматрао да би требало да гласе у духу изворне народне песме. Вук се овом баладом бавио дуго и савесно о чему сведоче не само његове две редакције већ и његова потреба и нада да Хасанагиницу нађе „у народу”. Суочивши се већ на самом почетку са психолошки крупним питањем изворности текста, у напору да одгонетне психолошки и језички смисао појединих израза и стихова и да утемељи чишћу и јаснију верзију од Фортисове, Вук је оставио по страни карактеристичну структуру садржине ове баладе и превидео потребу адекватног распореда, јер је и она песма „на међи”, што се рефлектовало у његовој другој редакцији Хасанагинище која је доспела у III књигу јуначких песама. Изостављајући Хасанагинииу из свог другог издања народних песама Вук се надао да ће је наћи живу у народу а кад му се нада није остварила, поново је редиговао већ постојећу своју редакцију и унео је у треће издање народних песама. Друга редакција и године које су је делили од прве сведоче о Вуковом настојању да Хасанагиници врати њену првобитну чистоту облика и значења. Сврставајући је, међутим, међу јуначке песме, иако у контексту сродних песама, Вук је показао мање доследан став него према осталим песмама „на међи”. 
Имајући иза себе богато искуство у непосредном раду и научно сазнање природе усмених творевина, Вук је у Предговору лајпцишком издању народних песама уобличио своје искуство до дефиниције појединих врста усмене књижевности: „Ђекоје су пјесме тако на међи између женскије и јуначкије, да човек не зна међу које би и узео (...) Оваке су пјесме наличније на јуначке него на женске, али би се тешко чуло да и људи пјевају уз гусле (већ ако женама), а због дужине не пјевају се ни као женске, него се само казују."

Из наведеног текста очевидно је да је Вук непогрешиво осетио суштинска обележја песама „на међи” иако није улазио у разлике унутар тих песама, у разлике између балада и романса. Гледајући их у збиру заједничких својстава Вук их је и распоредио тако да оне махом стоје једне уз друге. Према Вуковом мишљењу и искуству песме „на међи” не певају се као јуначке уз гусле, а њихова дужина чини да се не певају ни као женске већ се само казују, што је Вук нарочито нагласио. Из овога се могу уочити главна обележја балада и романса: оне садрже у себи лирски и епски елемент истовремено а казивање је главни начин извођења. Следствено томе, у песмама „на међи” од пресудног је значаја оно што се казује, тј. догађај чији исечци образују радњу. Казивање као начин извођења указује да се садржина помно прати као што то бива и код епских песама. Одвајајући песме „на међи”, Вук је опазио да њихови сижеи нису јуначка очитовања што почивају на потпуној или мање поузданој историјској основи већ да се оне односе на простор човековог личног и породичног живота као што то бива и код лирских песама.

Следећи своју мисао Вук је дао и примере песама којима није место ни међу женским ни међу јуначким. У том простору Вук није ишао до краја и није показао потпуну сигурност у распореду песама ако се оне гледају појединачно, али су зато његова опажања о појединим песмама или целинама песама драгоцен путоказ. Будући да је Вук био научник од крупних захвата чија се делатност ни из далека није заустављала само на народним песмама, њему је промакло много тога што је данас, пажљивим читањем, видљиво из његових збирки песама. Из Вукове колебљивости према коначном распореду песама, посебно када је реч о Хасанагиници, произашла је и оцена Максимилијана Брауна по којој у Вуковој I и V књизи женских песама нема балада (и романса) већ су то женске епске песме које примењују или опонашају готове шеме епског начина

1 Вук Стеф. Караџић, Српске народне пјесме, књ. I, Београд, 1953, стр. XVIII. 
казивања. ${ }^{2}$ Такав закључак не може се извести ако се уложи напор да се Вукове збирке женских песама сагледају у неопходној систематичности коју Вук није успео или није стигао извести до краја али којој је био на сигурном трагу.

Осим карактеристичне напомене којом је Вук попратио Хасанагиницу а која не додирује проблем класификације, од немалог је значаја напомена која стоји испод прве од четири верзије Омера и Мериме: „Ова пјесма и све три за њом иду међу јуначке, или барем међу оне између женскијех и јуначкијех; али их ја зато овђе мећем да би се боље виђети могло не само како су о једној ствари различне пјесме постале него и како се једне пјесме по народу различно пјевају. Смрт Омера и Мериме (...) ја сам први пут чуо у Тршићу 1803. године од једнога турскога Циганина из Босне, који ју је уз гусле пјевао; потом сам је слушао од много жена и ђевојака у Маџарској, и имао сам је сад преписану од много руку, из којијех сам изабрао ове три; но све ми се чини да ниједна није онако добра као што сам је први пут чуо". ${ }^{3}$

Овој Вуковој напомени треба одмах додати и једну другу којом је Вук пропратио романсу Чини Имбре Челебије: „И ова је пјесма више јуначка него женска, али ја је овђе мећем, као што сам метнуо и $342,343,344$ и 345" - каже Вук позивајући се бројевима на варијанте Омера и Мериме. ${ }^{4}$ Ове две напомене допуњавају једна другу и показују сталну Вукову двоумицу: јуначке или женске као ближа ознака за песме „на међи”. Ово колебање показује да Вуку није промакло да појам женске не одговара без остатка песмама типа Омера и Мериме иако се оне налазе у кругу женских љубавних песама. Именујући баладе о Омеру и Мерими јуначким песмама, Вук се несумњиво руководио критеријем њихове епске дужине. Али свестан непотпуности тог одређења у овом случају, Вук је мудро упутио да се оне сврстају „барем међу оне између женскијех и јуначкијех”. Тиме је Вук сам, не само својим начелима већ и њиховом непосредном применом, отворио могућност потоњим историчарима усмене књижевности а нарочито редакторима његових збирки да из замашног опуса издвоје оне песме које он сам није стигао до краја класификовати. Вук је показао неопходну меру флексибилности и својих начела и своје непосредне књижевне праксе. Својим напоменама Вук је заокружио једну малу збирку песама „на међи”, балада и романса, која није ни потпуна ни коначна али која то може постати уколико се иде путем који је сам Вук означио.

${ }^{2}$ Maximilian Braun, Zum Problem der serbokratischen Volksballade, Opera Slavica IV, Göttingen, 1963, стр. 151-174.

${ }^{3}$ В. Караџић, Српске народне пјесме, I, Београд, 1953, стр. 259.

${ }^{4}$ Исто, стр. 492. 
Вукове опаске о распореду песама резултирале су из његовог осећања природе појединих целина песама, а његово колебање показује јасно да је он увек судио на основу грађе која је нејединствена и променљива. Идући за дужином песама као критеријем у класификацији, Вук није пренебрегао специфичност садржине и њене природе. Варијанте Омера и Мериме, нарочито 344 и 345, епске су и по дужини и по подробном развијању радње. Стојећи пред песмама о Омеру и Мерими Вук је стајао пред песмама из круга тзв. баладних, лирских сижеа, чији сегменти образују радњу изневеравајући најзначајнији принцип поетике баладе, принцип редукције. За разлику од већине песама „на међи” из Вукове I и V књиге, песме о Омеру и Мерими разуђене су у радњу и показују очевидну епизацију сижеа од дословних понављања до епизода које немају битан значај за основну окосницу збивања, за сукоб на којем се баладе заснивају. Тиме се умањује и емоционална напрегнутост, битно својство балада, која описује унутарњу, оштру линију успона до климакса и пада до трагичног расплета. Вук је уочио епски карактер ових балада означивши га недовољно адекватним појмом јуначки али је песме унео међу женске будући да је био свестан лирског елемента у њима. Напокон, Вук је нашао средину између та два одређења а та је средина „на међи” што подразумева оба значајна чиниоца ових песама, лирско и епско.

И у другим појединачним случајевима који се заједно стапају у одређено научно искуство и сазнање, Вук је показао развијен смисао да у контексту одређене врсте песама препозна ону која битно одудара од тог контекста. Редактори Вукових народних песама, од Љубомира Стојановића па до наших савременика, поштовали су Вукове упутнице па су, из III књиге Српских народних пјесама бечког издања из 1846. године, преместили међу женске три песме које припадају скупини „на међи” означене бројевима 300а, 303а и 3036. Прва од њих интонирана је као романса о искушавању љубави а друге две су класичне баладе са карактеристичним сижеом окрутна мајка. У својој студуји Славјанская народная балада Николай Кравцов истицао је, уз Хасанагинииу, баладу Мати невјерница (303а) као потпун образац српскохрватских усмених балада. ${ }^{5}$ Напомена којом је Вук пропратио ове три песме показује да се он уопште није колебао упућујући их међу женске. Јер дужина ових песама није збуњивала Вука пошто није епска као што то није ни начин обликовања садржине.

${ }^{5}$ Н. J. Кравцов, Славјанскаја народнаја балада, Академија наук СССР, Уочнуе записки Института славјановеденија, 1964, т. XXVIII, стр. 226. 
Уважавајући и следећи Вукове напоре и критерије који су га у његовом послу руководили, узимајући у обзир тековине науке о усменој књижевности што су дошле после Вука, руководећи се властитим осећањем и сазнањем природе појединих врста усмене поезије, могућно је, из Вукове I и V књиге женских песама, издвојити добар број балада и романса које Вук није посебно издвојио. Оне творе засебан круг песама што чине целину обједињену одређеном каквоћом грађе и начином обликовања те грађе. Дакако, највише их има међу тьбавним и другим различним женским пјесмама, али и међу другим подврстама, и међу јуначким песмама.

Међу баладама се налази изразит број не само жанровски најчишћих песама већ и поетски усавршених до антологијских узора. Њихов број у Вуковој књизи је око 45 али је њихов састав у пуној мери репрезентативан. Овде ће бити наведени само најизразитији примери из тог круга песама: Неблагодарни син, Неблагодарни синови, Пречи муж од матере, Сестра отровница, Сестра сестри крвнииа, Мати невјерница, Смрт Ивана и Јелене, Смрт Омера и Мериме (бр. 343), Јане и Миленко, Три утоптеника, Мујо и Ума, Јанковица и заова Јана, Опет тврђа у вјери, Сеюанин Иво и юегова сестра, Жалосна ткала Јағь, Војин и сестра Иванова, Сестра Љутице Богдана, Неће Мара за бугарска бана, Милета и Милиц, љуба Јова Мрнаковића, Женидба Имраора Ненада, Бећирбег и Гиздаревићи, Џавербеговица и син јој, Асанага и юегова тьуба, Смрт Јанина и Ђурђева, Павловица и юезин ђевер Петар, Шуичкиға Мара, Ластавица и кукавица, Јаға мльезнииа, Јела удовииа, Снаха Јелена и ђевер Павле, љуба Малог Радојице, Јела Кружићева и мати јој, Несрећна беговица, Несрећна удаја, Гаја и ғегов ујак итд.

Овај избор указује на основне мотиве и комбинације мотива око којих се плету трагичне приче у баладама засноване на неспоразумима и сукобима у породици и међу људима: инцест, зла свекрва, сестра издаје брата, зла заова, неверна љубав, зла маћеха, зла снаха, несрећни љубавници и њихова заједничка смрт, трагичне насилне удадбе и женидбе итд. Видљиво је да међу овим, махом интернационалним, мотивима има и оних који припадају најстаријем слоју усмене традиције.

Међу романсама, којих има приближно колико и балада (око 45) у Вуковој І књизи, а које се заснивају на некој љубавној игри са духовитим заплетом и расплетом који растерећује и од којег нико не страда, нарочито су занимљиве оне које су потпуније развијене у радњи: Боље је злато и старо него сребро ново, Анђелина и Алибег, Марко и три Карлове шћери, Алајбег Јергече и кауркиюа дјевојка, Жалостива Ајка, Подмићена с обје стране, Челебија Рамо и љубовића кадуна, Чини Стојанове, Чини Имбра Челебије, Заручница Ериега Стјепана, Болозоновић, Болест Муја 
Царевића, Цетиюка и Мали Радојица, Јелена и бан, Доротија и војвода Јанко, Три кћери Омербеговице итд.

У Вукову V књигу женских песама у редакцији Љ. Стојановића ушла је, поред осталог, и цела збирка коју је Вуку послао Вук Врчевић Српске народне пјесме из Хериеговине, женске дања унео је ову збирку од 362 песме у Вукову V књигу у измењеном редоследу. Врчевића збирка садржи добар број балада и романса међу којима, нарочито међу баладама, има десетине песама које се могу сматрати врхунским песничким остварењима у кругу песама „на међи”. Овде ће из V Вукове књиге бити поменуте само оне међу њима које остварују срећну синтезу лирског и епског, прожет драматичним сукобима и откривалачким дијалозима, психолошки продубљене називима троструких градираних понављања итд.: Несретно вјенчаюе, Мара и хајдук Јован, Несретни сватови, Ченна и смрт за родом, Свекрва кори невјесту, Несуђене Ајке Ајровића, Хасан и Алибеговиа, Јашик снахе и заове, Сватови Јован-бега, Немила смрт Маре и Ивана, Лијепа Зрнићева Јеле, Алфа зла удовица, Хоће брат да облуби сестру, Зла свекрва, Зла заова, Женидба Орловића Павла, Кавга међу двије јетрве, Женидба Несијевић Јова, Мајка крвница итд.

Укупан број песама „на међи” у Вуковим двема збиркама женских песама износи близу две стотине, где је однос између балада и романса приближно пропорционалан. Ако би оне стајале једне уз друге у природном контексту и низу, сродност у сижеима у смислу усмерености према човековом личном животу, а нарочито специфична структура чинилаца сижеа, показали би се без двоумице. Та збирка била би потпуна када би се у њој налазила и балада о племенитој Хасанагиници, потом балада Браћа и сестра, романса Хајка Атлагића и Јован бећар, да поменемо само неке од оних које се налазе у Вуковим збиркама јуначких песама.

Број песама „на међи” који је овде назначен не треба узети као коначан јер има песама које су очевидно лирски фрагменти некадашњих целина песама „на међи”, као што има и епских које су проширене баладе или романсе. Ова замишљена збирка има своје оправдање утолико што омогућава да се уочи граница и разлике између лирских и епских песама, с једне стране, и песама „на међи”, с друге стране.

Оно што је сродно епским песмама и песмама „на међи” јесте приповедни елемент и казивање у трећем лицу. Међутим, догађај о којем се приповеда у радњи и дијалогу не износи се епски интегрално већ се

${ }^{6}$ В. Караџић, Српске народне пјесме из Херцеговине (женске), у Бечу 1866.

7 У овој Вуковој књизи романса је нешто више (око 50) него балада (око 35). 
исказује само у битних етапама, што произилази из принципа редукције оствареног у највећем броју балада. Лирски елеменат у балади, више него у романси, може се довести у везу са једним особитим углом гледања на одређени догађај, што је свакако у великој мери овисило о женама ствараоцима или казивачицама. Песме „на међи” по правилу прате судбину жене која је махом главна јунакиња, али је и суптилност која се показује у откривању унутарњег света жене поглавито резултат женске природне осетљивости и осећајности, што се превасходно односи на баладе. Зато је у њима остварен један дубљи емоционални проток који није статичан већ природно и нужно динамичан. Пошто до сукоба по правилу доводе осећања градирана до страсних очитовања и продора, на првом месту љубав и мржња, понашање јунака балада је страсно и непредвидиво и оно острашћује ситуације у којима се јунаци исказују. Специфичан угао осветљавања појединачне судбине и њеном унутарњем динамизму доводи до спрезања радње и нарушавања оног континуитета који налазимо у епским и јуначким песмама. Континуитет у простору и времену прекида се изостављањем небитног а хронологија догађаја постаје редукована и непотпуна хронологија значајних исечака догађања. Али се зато остварује, у највећем броју балада и знатно мањем броју романса, један дубљи континуитет унутарње каквоће који обједињује све што је изречено а сугестијом надокнађује прешућено, недоречено, лирским скоком ухваћено само у лету. То је емоционални континуитет динамичног успона или пада једног осећања, или развоја једног стања, које је осветљено само повремено, у блесковима, у лету, али у одсудним, преломним тренуцима збивања, у сегментима радње која изражава унутарње импулсе исказане у најизразитијим тачкама догађаја. У основи балада о Омеру и Мерими, без обзира на епску разуђеност радње, стоји унутарњи континуитет процеса развоја једног осећања до свести о том осећању, а у ту потку и изазване њоме уткивају се и друге нити и други токови који доводе до нових унутарњих покрета што се рефлектују у видљивом, у радњи. Љубав између двоје младих, од првог наговештаја до пуне зрелости и одлучности да се у име те љубави жртвује властити живот да би се она сачувала у својој духовној димензији, основна је и главна садржина балада о Омеру и Мерими. Из тог сабирног и истовремено дисперзивног сочива избија све остало и у њега се враћа: та љубав изазива материну забрану засновану на патријархалном породичном праву и моралу. У процесу сазревања љубави која је осуђена на пропаст и на том психолошком фону, светлосни зрак пада и на неумољиве законе патријархалне породице; исто тако уобличава се и емоционално продубљује унутарња ситуација силом доведене невесте а открива се врло сложен и душеван однос између ње 
и Омера. Енергија забрањене љубави доводи до битних, ширих промена које погађају све учеснике трагичног збивања. Али љубав је почетак и крај ових балада, од цветног орнамента на почетку до симболике цвећа на крају, до сублимације љубави између Омера и Мериме.

Балада о племенитој Хасанагиници оснива се на изненадном открићу деликатног неспоразума између мужа и жене што се у драматичној радњи умножава и услојава. Тај сукоб прераста у неразумевање између брата и сестре а у непосредном догађању открива се дубок унутарњи преображај који се исказује у највишем степену очитовања материнске љубави. Хасанагиничино биће исказује се у односу према мужу, потом према брату, у односу према деци, према новом просцу и, на крају, ова трагична невеста доживљава у једном тренутку све оно што је раније доживљавала у каквој таквој поступности. На том психолошком фону одвија се радња у снажним млазевима, а у зависности од те потке избија у сферу видљивог све оно што то драматично клупко сложеног и умноженог сукоба садржи. У снажној и сугестивној синтези свих чинилаца унутарње и спољашње радње у сцени расплета, смрт главне јунакиње значи једно могућно психолошко и уметнички дубоко засновано разрешење унутарњег судара у јунацима и између њих. Јер балада не приповеда о догађају већ се он непосредно догађа при чему се показују дубоке промене у сфери објективног и субјективног догађања.

И многе друге баладе остварене су као јединствени искази човекове осећајности која се, сугестијом и у динамици, осветљава у редукованом броју одсечака који творе садржину. Врчевићева балада Чежна и смрт за родом описала је само собом незаустављиву и смртоносну унутарњу путању емоције лепотице Низе: чежња за мајком изазива неприкосновену забрану мужа и његове захтеве за чије испуњење је потребан дуги низ година. Испуњење тих захтева, рађање девет кћери и девет синова, њихове удадбе и женидбе - све је то описано само у неколико стихова јер је у функцији унутарње потке збивања. То су заправо само етапе развоја и раста чежње за мајком и родом. Испуњавање захтева само је један низ који исказује нешто унутарње: градирање већ постојеће чежње до степена када је Низина смрт неизбежна. Сусрет са родом пролази нежно и без речи јер Низино срце више не може да издржи остварење дугогодишње и силом потискиване жеље. Све то казано је у непосредном догађању само у 35 стихова.

За разлику од балада, романсе показују посве другачији однос према неком догађају из човековог личног живота. Није реткост да су то исти догађаји који чине окоснице балада, али развијање ситуација, тумачење и вредновање људских поступака битно је другачије. Ако је основна окосница, на пример, прељуба, романса ће је по правилу опевати 
као слабост тела и срца коју у њеној елементарности не може ништа зауставити. Неке романсе откривају зачуђујуће висок степен толерантности према греху. У њима не постоји кобно и трагично осећање греха, страха од кривице, од мистичне уроте судбине, од трагичних околности и човекове предодређености да буде њихова жртва, као што је то случај од баладе до баладе. Нема обавезне казне нити одмазде, нема жртве ни страдања. Романсе су прожете ведрином и хумором што избијају из смелих и двосмислених дијалога, лукавстава, подвала, опклада, љубавних интрига итд. Оно што је у баладама табу, еротска сфера људског живота, то је у многим романсама опевано отворено, често бестидно, али и са рафинираном осетљивошћу за детаљ, са еротском фантазијом која се заокружује у изненадној поенти. Махом се све завршава тријумфом телесне љубави јер пут до љубави није страдање већ домишљатост, лукавство, игра. Све што је у баладама скривено у романсама је намерно индискретно откривено, а после открића тајне исход се даде предвидети. Хајка Атлагића и Јован бећар 8 потпун је пример тог друкчијег, романси својственог виђења култа огњишта, мајке и брачне везе. Породичне узе падају пред налетом силне и ослобођене природне чулне жеље. Верска међа између двоје младих губи се пред силом остварене љубави. Лаконско, готово пословично објашњење које Хајка упућује на крају својој мајци, указује на однос према врховном ауторитету породице који је потпуна супротност истом том односу у баладама и већини епских песама. Бестидно признање „како Влаше плаховито љуби” и чак савет мајци да оде „стара за каура", показује темељно другачији однос према патријархалном култу одређених вредности и норми понашања. Ни стида ни кајања нема у чину љубави, ни срамоте ни страха, ни поштовања друштвеног положаја угледне породице, ни обазирања на законе вере. Нагон за љубављу чини онај живи крвоток који струји у великом броју романса и пред тим нагоном владајући морални кодекс бива исмејан или пародиран јер морални суд који би осудио понашање јунака нема никаквог значаја. Сумрачју метафизичких сила које гоне човека у баладама, супротставља се ведра делотворност човекове потребе да свој живот учини радосним, да му се насмеје ако треба, да грубо наруши оно што је уобичајено и устаљено, да хумором и смехом победи и ублажи горчине, да релативизује моралне и друштвене норме, да у игру уђе спреман и изађе срећан.

Ако је балада трагична поезија које уноси страдање за један људски идеал и упркос поразу, романса је оваплоћење „еротске дијалектике”. Ако је балада израз човекове угрожености и страха, од физичког до

${ }^{8}$ В. Караџић, Српске народне пјесме, III, Београд, 1954, бр 19. 
метафизичког страха од непознатног, онда је романса израз слободног и ослобођеног човека који жуди за оним што му је доступно не марећи за оно што је изнад његове моћи. Ако је балада слојевит израз душевне драме човекове, романса је продор у чулни ковитлац људског бића. У романсама је све учињено спољашњим док је балада продор према унутра при чему је уочљива стваралачка дисциплина и тежња да се сугестијом више искаже но што се казује. Баладе и романсе су два различита вида транспоновања реалности живота у сферу поетског казивања.

Песме „на међи”, структуром својих чинилаца, нарушавају оне схеме и законе на којима почивању епске и лирска структура. Иако приповедање по правилу тече у трећем лицу, епска дистанца губи своју устаљену функцију и смисао јер грађа на којој се оснивају песме „на међи” не обавезује ствараоце и преносиоце онако строго као што то бива код епског певања. Догађаји о којима се пева са присношћу могући су и блиски човеку, свакодневни и без ореола „националне прошлости”. У сфери реалног живота могућност обнављања истих сижеа увек је отворена. Јунаци су махом анонимни а и кад нису, баладе и романсе не осветљавају спољашњи просто нити портрет јунака који се очитује у епској димензији свога деловања. Светлосни млаз усмерен је на откривање унутарњег бића човековог па су и описи, уколико постоје, допуне унутарњем, психолошком портретирању јунака, што се у првом реду односи на баладе.

Вукове песме „на међи”, разасуте у зборницима женских и јуначких песама, образују значајну и посебну збирку у којој је могућно препознати не само све одлике њихове поетике, каткад у бриљантној синтези, већ и слојеве грађе која се вековима слагала, од древних заједничких мотива до историјски условљених специфичности у њиховој обради. Израз на међ $и$, иако може да изгледа неодређен, погађа суштинско својство балада и романса, својство синтезе лирског и епског у њима.

* Рад је претходно објављен у зборнику Научни састанак слависта у Вукове дане, 3, 457-465. 